\title{
System dynamics modelling for defining livelihood strategies for women smallholder farmers in lowland and upland regions of northern Vietnam: a comparative analysis
}

\begin{abstract}
This study aims to compare the main determinants of the quality of lives and livelihood options for women smallholder farmers between the lowland and upland regions of northern Vietnam. A systems approach and relevant systems tools were used to develop rich pictures (systems models) that depict the current situations and interrelationships amongst different factors within the systems. The comparative analysis showed similar and distinctive characteristics of the farming systems and women farmers in the two regions. Patterns of relationships and interplays amongst different variables reflect the complexity and multidimensional nature of the lives of the women, who are part of and influenced by the interwoven social, economic, cultural and environmental systems. The study provided insights and practical guidance for making "strategic decisions" towards sustainable agricultural systems and livelihoods of the target group in the respective regions. The systems approach, framework and process steps employed in this study are of a generic nature and can therefore be applied to solve complex problems in various other contexts around the world. Theoretical and practical contributions of using systems approaches in agricultural research and development are discussed.
\end{abstract}

Keywords: Agricultural systems; Livelihoods; Systemic interventions; System dynamics modelling; Women smallholder farmers.

\section{INTRODUCTION}

Vietnam has a poor and an agriculture-based economy in South East Asia. The country consists of more than 10 million small farms (Hazell \& Rahman, 2014). Agricultural 
production provides the major livelihood for the rural poor (Ha et al., 2015b). Small-scale rice-based production and land fragmentation are typical characteristics of the farming systems in Vietnam (Van Hung et al., 2007).

In the northern part, there are two distinctive regions. The Red River Delta (RRD) represents a flatland paddy-based production area, being ranked as the second largest rice production region in the country, where most of the major ethnic group (Kinh or the Vietnamese) resides (Chi \& Fujimoto, 2012; Le, 2014). The Northern mountainous region (NMR) is the poorest region of the country with complex terrain forms and diversified cultures of more than 30 ethnic minorities (Vien, 2003). Local people are facing various challenges, particularly poverty, poor agricultural yields, land degradation (Yen et al., 2013) and distant markets (Castella et al., 2005). The NMR is divided into three zones, namely, high, low and midelevation mountain zones. Local people adapt their agricultural systems based on the specific environmental conditions and their traditional habits. Typical agricultural systems according to the zones include "rock-pocket agriculture", "composite swiddening" and "agroforestry" systems, respectively (Vien, 2003). Both the RRD and NMR share a common feature, namely a significant level of gender inequity, particularly women smallholder farmers in rural areas (Ha et al., 2015b; Trinh et al., 2015).

Development efforts in improving living standards of rural poor households and promoting gender equity have recently been given a high priority by the central and local governments (IFAD, 2013; Kelly, 2011). This is because gender inequity has been evident in many regions of the country, including the two aforementioned regions (FAO, 2010; Kabeer, 2003). Women are the major labourers in both domestic and production tasks. Their work burdens, together with the old customs against women, were reported to hinder their educational and job opportunities, participation in social activities, and access to productive resources. In contrast, men have more opportunities moving to work in non-agricultural sectors (Ha et al., 

and raising income for women farmers could improve their social status, decision making power and improved quality of life, particularly in northern Vietnam (IFAD, 2011; Lapar et al., 2006).

Given that women farmers are part of rural households and farming communities, addressing issues faced by them requires a holistic and multidisciplinary approach. According to Spedding (1988, pp.8-9), it is misleading to only focus on agriculture itself when studying an agricultural system. Due to its multi-disciplinary nature, agriculture involves mixtures of disciplines such as social sciences, economics, biology, etc. Furthermore, Villarreal (2000) has proven a strong influence of local culture on agricultural production. This author also highlighted the complexity of the situation in which gender-related issues were studied under a gender system. The gender system is part of and influenced by bigger systems in which relationships between socio-cultural, economic, political and historic factors are all interwoven.

Many development efforts have been proven inappropriate due to the complex issues in agriculture and rural development in the northern region. For example, a lack of understanding of local conditions, culture and capability has been reported as main causes that led to various failures in technology transfer and livelihood development programs (Vien, 2003; Vien et al., 2006). Culas (2012) criticizes many drawbacks and failures in agricultural development projects in Vietnam, which are mainly due to the lack of a "multidisciplinary approach" from design to implementation. Few studies focus on "socioagricultural dynamics and changes". Linear thinking in technology transfer that leads to unintended consequences on resource-poor women smallholder farmers has also been reported by Paris and Chi (2005). Therefore, various issues in agriculture such as the vicious cycle of poverty, negative debts, unsustainable livelihoods and gender inequity are still 
unresolved problems that affect many disadvantaged groups, particularly the women smallholder farmers in many regions (Bosch et al., 2015).

Taking the above into account it is clear that a more holistic and multidisciplinary approach is required for better understanding of the context and subsequently the nature of interventions that are required. Systems thinking approaches, modelling tools and decision support systems have been used in agricultural systems research and development around the world (e.g. Bawden, 1991; Eastwood et al., 2012; Florin et al., 2013; Lamprinopoulou et al., 2014; Macadam \& Packham, 1989; Mainland, 1994; Paracchini et al., 2015). However, so far no study has been conducted using systems dynamics modelling to analyse and compare the complexity of women farmers' determinants of life and the interactions amongst different subsystems beyond the production systems in the two regions of Vietnam. This study will contribute to addressing the current knowledge gap through an in-depth analysis of the women's situations and provide both policy and practical recommendations to improve their livelihoods and quality of life.

Due to the distinctive differences in terms of natural, social and cultural characteristics between the lowland and upland regions, farming systems and specific challenges of women farmers in the two regions reveal their own nuances (Ha et al., 2015b; Trinh, 2014). This study therefore aims to compare general characteristics and the main determinants of the quality of life of women farmers and provide insights for defining appropriate livelihood

94 options for each region using a systems approach.

\section{APPROACH AND METHODS}

\subsection{Overall approach and study locations}

97 The study employed a systems approach with relevant systems tools (described below) in two regions, lowland and upland (Figure 1) of northern Vietnam. Haiphong is a typical lowland

99 province in the Red River Delta. The province has a total natural land area of $1,519 \mathrm{~km}^{2}$, 
including two islands, with an average elevation of $0.7-1.7 \mathrm{~m}$ above the sea level. Flatland constitutes $85 \%$ of its total land area. Haiphong is situated in the typical sub-tropical region of northern Vietnam with an annual average temperature of 23 to $26^{\circ} \mathrm{C}$ (depending on seasons). A population of more than two million was reported in 2016 (Gregorich, 2016).

104 Four rural districts of Haiphong, namely, Kien Thuy, An Lao, Vinh Bao and Tien Lang, were selected that represent the typical lowland area where there is a relatively large proportion of smallholder farmers, the key target group of this study.

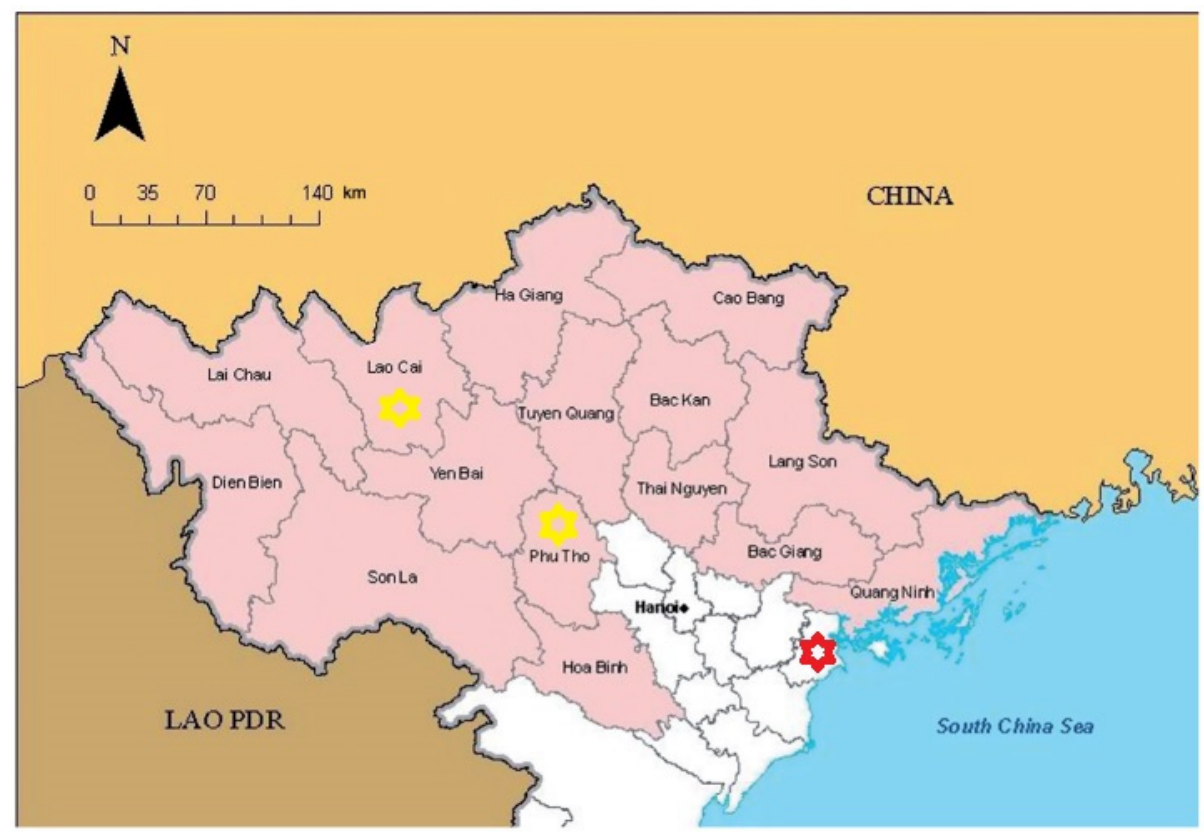

108 Figure 1 - Map of the research locations. Red star represents the research location in the lowland (Haiphong, the Red River Delta); Yellow stars represent the research locations in the upland (Northern Mountainous Region) (Source: Adapted from Clement \& Amezaga, 2013).

111 Phu Tho and Lao Cai provinces represent the northern upland and/or northern mountainous

112 region (NMR). Phu Tho is a typical midland province located in the sub-tropical monsoon

113 region with an average temperature of $23^{\circ} \mathrm{C}$ and annual humidity of $85 \%$ (FAO, 2012). The

114 province has a population of 1,351 people, being one of the poorest provinces in the Vietnam

115 (GSO, 2013). The province's total natural land area is $3,533.3 \mathrm{~km}^{2}$ (GSO, 2013). However, 
116 only $54.8 \%$ is considered arable for production (FAO, 2012). Meanwhile, Lao Cai represents

117 an upland province with the total land area of $6,383 \mathrm{~km}^{2}$ (GSO, 2013) and an average annual

118 temperature of $23^{\circ} \mathrm{C}$ (DARDLC, 2012; FAO, 2011). The province is a mosaic of 33 different

119 ethnic minority groups (LCPPC, 2011), contributing to roughly $65 \%$ of the total population

120 (656,900 people) (Culas, 2011; GSO, 2013). This province is one of the top-five poorest

121 provinces of Vietnam (Phi, 2012).

122 In Phu Tho province, Tan Son district was chosen. Bac Ha and Sa Pa districts were selected

123 in Lao Cai province. These three districts are amongst the poorest districts of Vietnam

124 (CEMA, 2010; UN, 2013). Women farmers in these districts are the most vulnerable group

125 (Trinh, 2014).

126 Due to the above mentioned reasons, women smallholder farmers in both regions were

127 chosen as the target group for this comparative study.

\subsection{Process steps carried out in the lowland}

129 The case study in rural Haiphong was conducted following the first five steps of the

130 Evolutionary Learning Laboratory (ELLab) (Bosch et al., 2013). The process started from

131 identifying issues and gathering mental models of relevant stakeholders via both baseline

132 surveys and stakeholder workshops to develop a shared understanding of the current situation

133 of the women farmers (Step 1). Representatives of the appropriate stakeholders were selected

134 for capacity building and learning-by-doing activities throughout the ELLab cycle (Step 2).

$135 \operatorname{Vensim}^{\circledR}\left(\right.$ Ventana $\left.{ }^{\circledR}, 2011\right)$ and Netica ${ }^{\mathrm{TM}}$ software (Norsys, 2013) were used to support the

136 development of systems models of the current situations, defining levers for systemic

137 interventions and developing an overall management plan (Steps 3-5) (Figure 2). 


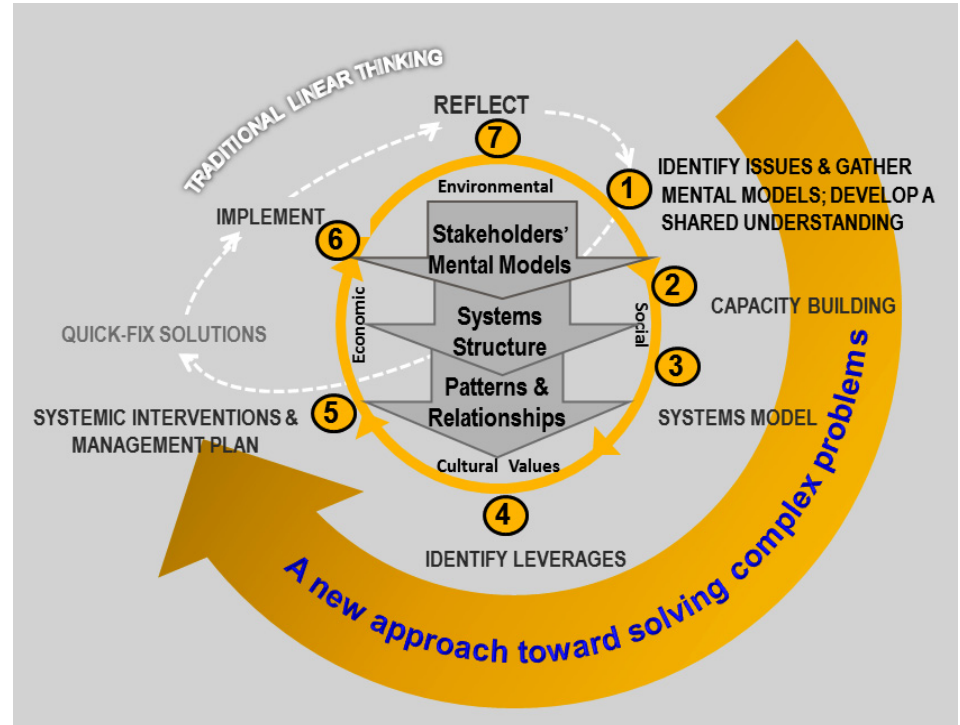

139 Figure 2 - Evolutionary Learning Laboratory for Managing Complex Issues under conditions of

140 interwoven relationships between economic, social, environmental and cultural factors (Source:

141 modified from Bosch et al., 2013).

142 In response to the requirements of the funding body (Gates-Foundation, 2013), which focused

143 on labour saving innovations and strategies for women smallholder farmers, the selection

144 criteria of participants in the ELLab processes were discussed and agreed between the 145 research team and the local partner, the Department of Agriculture and Rural Development.

146 Those include (1) being smallholder farmers in the research area; (2) geographic

147 representation of participants/informants; (3) balanced representation of ethnicity (if any);

148 and (4) balanced representation of rich, fair, and poor participants within the smallholder

149 women farmers in the area.

150 Both qualitative and quantitative data collection methods were employed through a baseline 151 survey with 33 smallholder farmers prior to a number of stakeholder workshops and separate 152 mini-workshops or forum discussions with women farmers in the four rural districts. The 153 baseline survey provided background information on the profile of households, current 154 production status, market outlets, gender-related issues, and labour use. The plenary 
workshops were organised with the participation of 75 representatives from the local government departments and organizations, input/service providers, women farmers, and agribusinesses in both Haiphong and a neighbouring province, Hai Duong. Representatives of agribusinesses were later engaged in the ELLab process due to the initial findings that highlighted the need for improving income via market actor linkages.

160 The mini-workshops were conducted in each district with the participation of $36-40$ women smallholder farmers for more in-depth understanding of their real challenges, expected solutions and how they are ranking what they regard as priorities.

\subsection{Process steps carried out in the northern mountainous region}

164 The case study in the NMR is a follow-up research activity from a baseline study on impacts of vegetable farming on livelihoods of women farmers in two selected provinces, Phu Tho and Lao Cai (Trinh, 2014). However, by using a systems approach, the follow-up analysis

167 provided a broader picture and interrelationships of all factors determining the livelihoods of

168 the rural women rather than a mere focus on production of a single crop.

169 In addition to the main variables defined from analyses of the baseline study (Trinh, 2014),

170 relevant secondary data were collected from reports and other published sources of different

171 international and domestic organizations, such as the Australian Centre for International

172 Agricultural Research (ACIAR), Vietnam Women's Union, Vietnam Academy of

173 Agricultural Sciences, Provincial Departments of Agriculture and Rural Development, and 174 previous studies in the two provinces to support findings. Vensim ${ }^{\circledR}$ software (Ventana ${ }^{\circledR}$, 175 2011) was used to develop a causal loop diagram (CLD) that depicts the current situation, 176 highlighting patterns of relationships and potential levers for systemic interventions to 177 improve their lives. 


\subsection{Description of concepts and their implications}

179 The patterns of relationships denote how different variables are interlinked and the nature of

180 feedback loops that are formed, either reinforcing or balancing loops (Bosch et al., 2013).

181 The reinforcing feedback $(R)$ loop represents positive feedback, showing "growing or

182 declining actions". In contrast, the balancing feedback (B) loop indicates negative or

183 counteracting feedback, which "seeks stability or return to control, or aims for a specific

184 target" (Maani \& Canava, 2007: 33). For example, Ha (2008) reported the traditional habit of

185 many Vietnamese farmers that applies untreated farmyard manure into their ponds. The

186 conventional practice causes a number of environmental and health concerns in rural areas.

187 Figure 3 illustrates two types of feedback loops. Applying untreated manure causes pond 188 water pollution in the long run. In turn, the latter induces a higher number of dead fish due to 189 the polluted water. The more fish dies, the worse the pollution of water becomes. This

190 feedback creates a reinforcing (R) loop. The polluted condition of pond water and the

191 increased number of dead fish influence farmers' awareness. Therefore, application of

192 untreated manure is reduced (balancing loops, B1 and B2, Figure 3), seeking alternative

193 methods that are more environmentally sound.

194

195

196

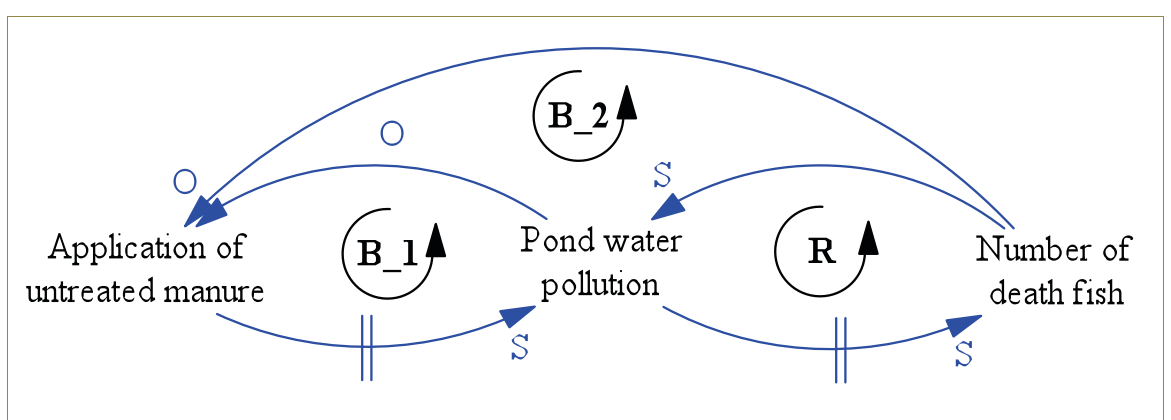

Figure 3 - Example of reinforcing (R) and balancing (B) feedback loops through the traditional practice of Vietnamese farmers applying untreated farmyard manure into their ponds. Legend: Arrows 
197 ( $\rightarrow$ ) indicate the causal links; Arrows with a double vertical bar $(\rightarrow \rightarrow)$ represent a time delay; $S-$

198 same direction; $O$-opposite direction.

199 The patterns of relationships help to explain causal relationships and interactions between 200 different variables within a subsystem. They also show interplays amongst factors in the 201 subsystems. Analyses of these patterns enabled participants to understand the nature of 202 interconnectedness between different factors and the outcomes/consequences of an 203 intervention.

204 The leverage points are defined as "points of power" or "places within a complex system (a 205 corporation, an economy, a living body, a city, an ecosystem) where a small shift in one thing can produce big changes in everything" (Meadows, 1999: 1).

207 Identifying the leverage points within a system helped to develop a systemic action plan for

208 coordination of proposed systemic interventions that produce high impacts towards achieving 209 the defined goal. It seeks to improve the whole system performance rather than the traditional 210 approach of linear thinking, leading to "quick fix" solutions and various unintended 211 consequences and even counterproductive outcomes (Bosch et al., 2013; Ha et al., 2015c;

212 Maani, 2013; Sterman, 2001; Vester, 2007).

\section{III. RESULTS AND DISCUSSION}

\section{3.1. System dynamics model of the current situation of women farmers in the lowland}

215 Figure 4 shows a systems model developed from the synthesis of all mental models of the

216 women farmers and related stakeholders concerning different issues affecting the lives of the

217 women in rural Haiphong. Analyses of relationships patterns revealed the interwoven 218 relationships and interplays amongst the variables. 


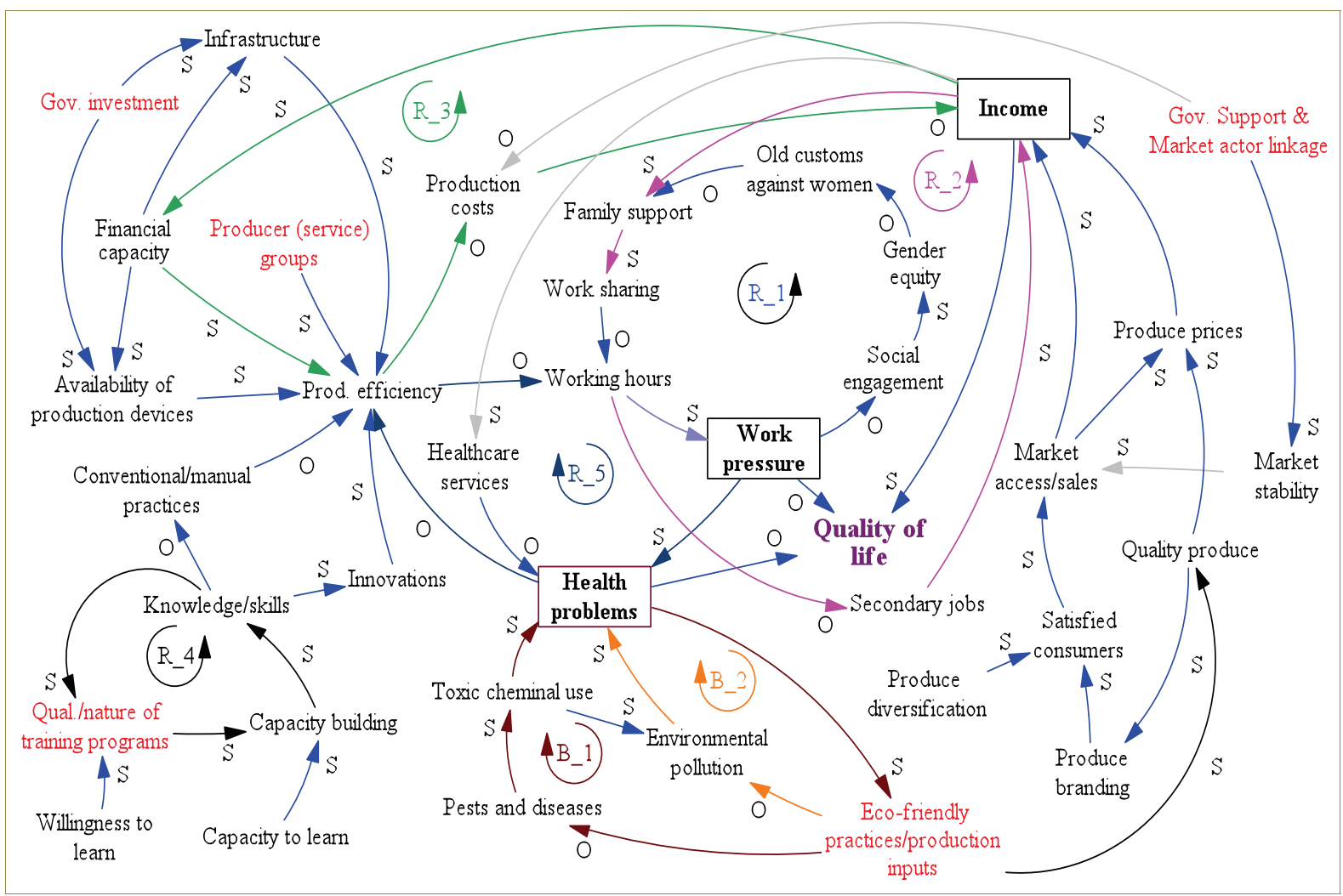

220 Figure 4 - CLD modelling for improving the quality of life of women small farmers in rural

221 Haiphong. Legend: $S$ - same direction; $O$ - opposite direction; $R$ - reinforcing (feedback loop); $B$ -

222 Balancing (feedback loop) (Source: adapted from Ha et al., 2015c).

223 Low income, high work pressure and poor health were, in order of importance, determined as

224 the three major challenges that the smallholder women farmers are facing. Therefore, raising

225 income, reducing workload and improving health were set as the three main objectives to

226 achieve the goal of improving the quality of life of the women.

227 The systems model enabled participants to better understand the current situation, 228 interrelationships amongst the variables and the need for engagement of all relevant 229 stakeholders. The identified patterns of relationships helped the participants to determine 230 potential important factors (red variables, Figure 4) that can change the system's 231 performance. 
232 The results clearly show that factors determining the quality of life of the women farmers are way beyond their production systems. Their production-related labour hardship, the focus of

234 the funding body, is just part of the big picture of interrelated factors that altogether influence

235 their lives (Figure 4). The women's uttermost need is to raise their income through improved

236 market access, which can address many other issues. Their increased income was stated to

237 strengthen their financial capacity for investment in production and access to productive resources. It will help to improve production efficiency and thus reduce cost and increase savings (R3, Figure 4). The raised income implies a higher status within their family, resulting in better family support and work sharing. As a result, their work hours are lessened, creating more opportunities for them to earn additional income via secondary jobs (R2, Figure 4). The reduced workload enables them to participate in social activities and organisations that will improve their knowledge, skills and subsequently status. This could lead to improved gender equity, gradually removing old customs against women and thereby better family support and work sharing (R1, Figure 4). The results are consistent with finding of Lapar et al. (2006) and IFAD $(2011,2013)$ in other provinces in northern Vietnam. In addition, the improved production efficiency reduces their work pressure and therefore improved health, which in turn further enhance production efficiency (R5, Figure 4).

The developed model helped all the stakeholders to understand their role and areas of

250 possible support that need their involvement. Further steps in defining systemic interventions,

251 testing future scenarios for developing an integrated management plan towards the end goal

252 are presented in Ha et al. (2015c), which is beyond the scope of this article. 
255 Due to the specific challenges in the upland, local people, particularly women farmers, have

256 to face a range of difficulties. There are many hindrances to livelihood improvement. Those

257 include distant markets, inappropriate cropping structure, production risks, limited literacy

258 level, language barriers, gender inequity, small landholdings, subsistence production habits,

259 and food insecurity (Trinh, 2014; Trinh et al., 2015). These issues were multidimensional and

260 intertwined with one another. Together they influence the lives of the women in particular,

rural households and farming communities in the NMR in broad terms.

262 Food security, income, equity, and health and leisure were determined as the key

263 determinants of the livelihoods of the women farmers in the NMR (Figure 5).

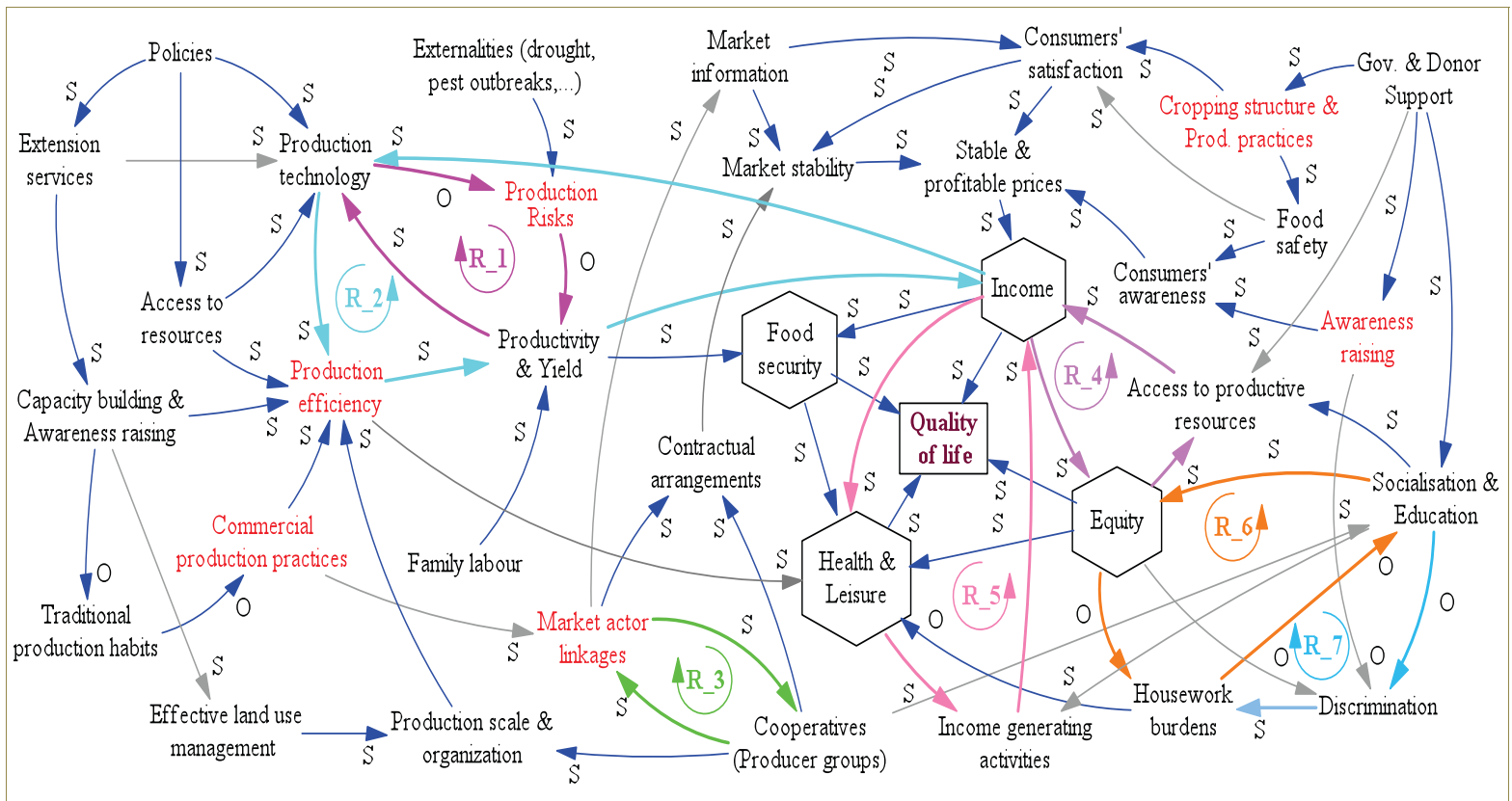

266 Figure 5 - CLD modelling on improving the quality of life of women small farmers in the NMR.

267 Notes: $S$ - same direction; $O$ - opposite direction; $R$ - reinforcing (loop). Red coloured variables are

268 potential leverage points for systemic interventions (Source: adapted from Trinh et al., 2015).

269 The systems model developed following the analysis of the baseline survey has provided a 
important factors (red variables, Figure 5) that could leverage performance of the whole system. Interventions focusing on these factors would be expected to yield high impacts on improving the quality of life for the women and farming households in the highland (Figure $5)$.

Due to harsh biophysical conditions in accordance with the traditional subsistence production habit of local residents in this region, food insecurity was stated as the most challenging issue, in which a large proportion of households have to face several months of food shortage (Trinh, 2014). Addressing this issue through mainly enhancing production efficiency and reduced production risks can be considered critical before addressing their need to raise 280 income and others.

281 Productivity and yield of agricultural products are important for food security. Improving 282 production efficiency would be the key to address the current issue of poor yield. This requires policy support in terms of access to productive resources, production technology and

284 extension services (including capacity building) to help change their subsistence production

285 habits and cropping structure to be more commercial and profitable, and thereby have more secure and increased income (Figure 5). The results are consistent with findings of Minot et al. (2006) and Nguyen (2012) in the NMR. The increased income would enable the smallholder farmers to access production technology that would directly lead to improved

289 production efficiency (R2, Figure 5). Their access to improved technology also helps to 290 reduce their production risks, resulting in more secure and increased agricultural yield. This 291 would be a motivation for them to adopt production technology (R1, Figure 5).

292 Their improved production efficiency and income would result in improved health and leisure 293 time for the women. Bosch et al. (2015) found that increased income enables women 
294 smallholder farmers to have better access to healthcare services, while improved production

295 efficiency lead to more free time. In this case study, their enhanced health and leisure would

296 enable the women to participate in other income activities to raise their family income (R5,

297 Figure 5). Their raised income would also improve their social status, promoting gender

298 equity, which results in better access to productive resources and thus income (R4, Figure 5).

299 Their raised social status and more equity would lead to reduced housework burdens and thus

300 more time for social and education activities, which would further promote gender equity

301 (R6, Figure 5). The outcomes are consistent with findings of Bosch et al. (2015) and IFAD

302 (2013).

303 3.3. Comparative analyses of general characteristics of farming systems and factors influencing the quality of life of women farmers in lowland and upland regions

\subsubsection{Similar characteristics}

306 First, the rural women and farming households in both regions have to face a number of

307 similar challenges which are multidimensional, interconnected and related to multiple stakeholders such as market actors, service providers, extension networks and local governments. The systems models (Figures $4 \& 5$ ) clearly show that the farmers live and work within a complex web of interdependent subsystems (environmental, political, social,

311 economic and cultural), which are beyond their farming/production systems. For example,

312 Figure 4 shows that labour hardship of the women in Haiphong is influenced by (1) old 313 customs against women (cultural factor) leading to their production and domestic work 314 burdens; and (2) conventional labour intensive production practices (production system). To

315 reduce work pressure the stakeholders stated the need for government support (political 316 factor) with regards to production infrastructure, access to production implements, regulating 
317 input prices, and strengthening the extension network for effective capacity building. In

318 addition, institutional support for local production service groups and cooperatives were

319 found equally important to facilitate work sharing and production efficiency. Forming formal 320 cooperatives via land consolidation on voluntary basis amongst individual farmers was stated

321 as one of the requirements for the success of smallholder agribusiness and thus their income

322 (economic factor). The recent baseline survey (Ha et al., 2015b) indicated that conventional unsafe production using toxic chemicals is amongst the contributing factors to polluted environment (environmental aspect) and poor health, which influence their production efficiency. Raised income was also reported to have multiple benefits in access to healthcare services and productive resources, improving their status within the family and community (social factor), and thus improved family support and work sharing (Figure 4). Similar nature of interactions between the variables within a subsystem and their interplays with variables of other subsystems is also evident in the upland as indicated in Figure 5.

Second, land fragmentation, small-scale production systems and conventional practices have also been reported to hinder market access and thereby poor and uncertain income for the farmers in both regions (Ha et al., 2015b; Trinh et al., 2015). For example, the production land areas in rural Haiphong and Phu Tho are 0.31 ha and 0.58 ha per household, respectively (Ha et al., 2015b; Yen et al., 2013). Results are also consistent with findings of various studies in developing countries regarding the barriers to market access of smallholder farmers (e.g. Barrett et al., 2012; Fischer \& Qaim, 2012; Hazell, 2005) and findings of Minot and Hill

337 (2007) in the uplands and peri-urban areas of Vietnam.

338 Third, being smallholder farmers in a poor country, their production is highly dependent on supporting policies and orientation (political factor) of the central and local governments.

340 This is similar to the characteristics of smallholder farmers in other developing countries such 
341 as those in Sub-Saharan Africa (Bosch et al., 2015). For example, funding and support from

342 the governments for production infrastructure (roads, power grid and irrigation canals),

343 regulation of prices of inputs (e.g. fertilisers, pesticides), capacity building via the extension

344 network, and promotion of market linkages were found essential in the lowland (Figure 4).

345 Similar aspects of support are also evident in the NMR (Figure 5). Some slight differences

346 regarding the political factors between the two regions, as well as the requirements that

347 farmers have to address are presented in Subsection 3.3.2.

348 Finally, the systems dynamic models in the two regions denote several similarities. In both

349 regions, factors such as changing production practices and organisation, and enhancing

350 market actor linkages to improve income for the women in particular, rural households and

351 farming communities in broad terms were found to be important. Extensive use of chemical pesticides in both regions (Ha et al., 2015b; Pham \& Smith, 2013; Trinh, 2014) could be seen as an implication of unsustainable production systems. It is also a contributing factor to poor quality produce and health of the producers. Additionally, the need for engaging the women in social activities and capacity building to improve their status and thus gender equity are also asserted in both regions (Figures 4 \& 5). According to Nghiem (2010), enhancing education levels would improve farmers' livelihood options. However, the authors argue that education would be a long-term objective while the basic needs are being addressed (for example, food security, health and income). A study by Safa (2005) in Yemen showed that

360 education level does not have significant influence on income of smallholder farmers in the

361 highlands, but it has significant impact in the lowlands. Furthermore, a large number of 362 studies has proven that informal capacity building and social engagement for marginalised women could improve their livelihoods and promote gender equity via improved knowledge, 
365 by men (Bosch et al., 2015; IFAD, 2011, 2013; Lapar et al., 2006; Minot et al., 2006).

\subsubsection{Differences between the two regions}

367 Due to the evident differences in regional settings (natural and human aspects), factors

368 influencing the livelihoods of women smallholder farmers in the two locations also have

369 distinctively different characteristics.

371 Table 1: Differences in general characteristics of farming systems and main factors influencing the

372 lives of women smallholder farmers in lowland and upland regions

\begin{tabular}{|c|c|c|}
\hline Indicators & Lowland region & Upland region \\
\hline $\begin{array}{l}\text { Biophysical } \\
\text { conditions }\end{array}$ & $\begin{array}{l}\text { Flatlands and ease of water access for } \\
\text { irrigation that are favourable for land } \\
\text { consolidation and mechanisation in } \\
\text { agriculture to reduce labour input, } \\
\text { production costs, improve efficiency and } \\
\text { economy of scale to meet requirements of } \\
\text { businesses (Ha et al., 2015b, 2015d). } \\
\text { Market access is relatively easier than that } \\
\text { in the NMR. }\end{array}$ & $\begin{array}{l}\text { Hilly and mountainous topography and } \\
\text { rain-fed areas, and high production risks } \\
\text { due to harsh environmental conditions } \\
\text { and pest damages (Trinh, 2014; Trinh et } \\
\text { al., 2015; Yen et al., 2013). } \\
\text { Distant markets and limited access to } \\
\text { information (Linh } \text { et al., 2015; Trinh et } \\
\text { al., 2015). }\end{array}$ \\
\hline $\begin{array}{l}\text { Farming systems } \\
\text { characteristics }\end{array}$ & $\begin{array}{l}\text { Typical cropping systems in the lowland } \\
\text { Red River Delta are irrigated rice-rice, } \\
\text { rice-cash crop, and rice-maize systems } \\
\text { (Le, 2014). } \\
\text { In rural Haiphong rice-farming is the } \\
\text { dominant production system (Chi \& } \\
\text { Fujimoto, 2012; FAO, 2002). The system } \\
\text { has } 1 \text { to } 3 \text { rice harvests per year, depending } \\
\text { on water availability. Other subsidiary } \\
\text { crops such as vegetables, maize, root } \\
\text { crops, soybean, sugarcane and fruit are }\end{array}$ & $\begin{array}{l}\text { Diverse agricultural systems associated } \\
\text { with ecological zones and ethnic groups } \\
\text { (Vien, 2003; Yen, 2013); High proportion } \\
\text { of rain-fed production systems in hilly } \\
\text { lands (Minot et al., 2006; Trinh, 2014). } \\
\text { Rice, maize, cassava, sweet potato are } \\
\text { staple food crops in the NMR (Yen et al., } \\
\text { 2013). In which, rice contributes to } 46 \% \\
\text { of total crop production value (Yen, } \\
\text { 2013). } \\
\text { Family farming and subsistence }\end{array}$ \\
\hline
\end{tabular}




\begin{tabular}{|c|c|c|}
\hline Indicators & Lowland region & Upland region \\
\hline & $\begin{array}{l}\text { often integrated in the production system. } \\
\text { Livestock and off-farm activities are } \\
\text { significant sources of household income } \\
\text { (Dixon et al., 2001). Livelihoods of the } \\
\text { women smallholder farmers in this area are } \\
\text { dependent on crops ( } 55.0 \% \text { ) (mainly rice } \\
\text { and cash crops), and livestock production } \\
(30.3 \%) \text { (Ha et al., 2015b). }\end{array}$ & $\begin{array}{l}\text { production is the typical agricultural } \\
\text { system which is mainly based on manual } \\
\text { family and animal labour. Farm outputs } \\
\text { are mainly consumed by the family, small } \\
\text { proportion of the outputs is sold or } \\
\text { exchanged at nearby markets (Vien, } \\
2003 \text { ). }\end{array}$ \\
\hline $\begin{array}{l}\text { Farmers' } \\
\text { characteristics } \\
\text { (socioeconomic } \\
\text { aspect) }\end{array}$ & $\begin{array}{l}\text { The majority of women farmers and rural } \\
\text { households in the lowland belong to the } \\
\text { major ethnic group (Kinh or the } \\
\text { Vietnamese) (Vien, 2003). Commercial } \\
\text { production is evident in this region (Ha et } \\
\text { al., 2015b). }\end{array}$ & $\begin{array}{l}\text { Mainly ethnic minorities (approximately } \\
30 \text { groups) living in the region associated } \\
\text { with high level of illiteracy, language } \\
\text { barriers and subsistence production } \\
\text { practice and thus poor yield (Trinh, 2014; } \\
\text { Trinh et al., 2015; Yen et al., 2013). }\end{array}$ \\
\hline $\begin{array}{l}\text { Main determinants of } \\
\text { the lives of women } \\
\text { farmers } \\
\text { (socioeconomic) }\end{array}$ & $\begin{array}{l}\text { Three key determinants: Income, workload } \\
\text { and health, in order of importance (Figure } \\
\text { 4). }\end{array}$ & $\begin{array}{l}\text { Four key determinants: Food security, } \\
\text { income, gender equity, and health \& } \\
\text { leisure (Figure 5). }\end{array}$ \\
\hline $\begin{array}{l}\text { Food security } \\
\text { (socioeconomic) }\end{array}$ & $\begin{array}{l}\text { Food insecurity is not an issue of the } \\
\text { women farmers in rural households in the } \\
\text { lowland. This is probably due to the } \\
\text { favourable conditions of flatlands and the } \\
\text { ease of access to irrigation water for } \\
\text { increasing the number of crops per year. }\end{array}$ & $\begin{array}{l}\text { High proportion of households }(32-70 \%) \\
\text { facing food shortage for } 1-6 \text { months in the } \\
\text { selected communes of Phu Tho \& Lao } \\
\text { Cai. This is mainly due to high } \\
\text { production risks, conventional subsistence } \\
\text { production practices, inappropriate land } \\
\text { use management and poor access to } \\
\text { productive resources (Trinh, 2014; Trinh } \\
\text { et al., 2015). These cause uncertain and } \\
\text { poor yield (Figure 5). }\end{array}$ \\
\hline $\begin{array}{l}\text { Poverty level } \\
\text { (socioeconomic) }\end{array}$ & $\begin{array}{l}15.6 \% \text { and } 25.0 \% \text { of the interviewed } \\
\text { respondents belong to 'rural poor' and } \\
\text { 'marginal poor' groups with an average } \\
\text { income of less than USD } 1.0 / \text { person/day } \\
\text { (Ha et al., 2015b). }\end{array}$ & $\begin{array}{l}\text { Poverty rate in NMR is } 43.9 \% \text {, which is } \\
\text { higher than the average rate }(33.0 \%) \text { of } \\
\text { the northern provinces. However, the rate } \\
\text { of ethnic minority community reached } \\
67.4 \% \text { (Nguyen, 2012). }\end{array}$ \\
\hline $\begin{array}{l}\text { Market situation } \\
\text { (economic aspect) }\end{array}$ & $\begin{array}{l}\text { Availability of potential local enterprises } \\
\text { with high willingness for contract farming; } \\
\text { Huge potentials for agricultural produce in }\end{array}$ & $\begin{array}{l}\text { Distant markets and asymmetric } \\
\text { information due to the remoteness of the } \\
\text { farming communities. Lack of market }\end{array}$ \\
\hline
\end{tabular}




\begin{tabular}{|c|c|c|}
\hline Indicators & Lowland region & Upland region \\
\hline & $\begin{array}{l}\text { both domestic and export markets. } \\
\text { Therefore, market actor linkages via } \\
\text { contract farming are feasible (Ha et al., } \\
\text { 2015a, 2015d). A number of specialised } \\
\text { cooperatives have been developed in } \\
\text { Haiphong. }\end{array}$ & $\begin{array}{l}\text { focus due to the subsistence production } \\
\text { habits (Trinh, 2014). These would hinder } \\
\text { commercial development of agricultural } \\
\text { products. }\end{array}$ \\
\hline $\begin{array}{l}\text { Degree of gender } \\
\text { inequity (cultural } \\
\text { aspect) }\end{array}$ & $\begin{array}{l}\text { There is still a significant level of } \\
\text { engender inequity in terms of production } \\
\text { and housework tasks. However, decision } \\
\text { making power in production is not } \\
\text { significant different }(\mathrm{P}<0.05) \text { (Ha et al., } \\
2015 \mathrm{~b}) \text {. }\end{array}$ & $\begin{array}{l}\text { High level of gender inequity with a } \\
\text { strong conception that women belong to } \\
\text { kitchens and are not allowed to go to } \\
\text { school. They also become main caretakers } \\
\text { of their families (Trinh, 2014). }\end{array}$ \\
\hline $\begin{array}{l}\text { Supporting policies } \\
\text { of the central and } \\
\text { local governments }\end{array}$ & $\begin{array}{l}\text { Recent favourable policies through } \\
\text { development programs for both crop and } \\
\text { livestock development. Land consolidation } \\
\text { for the ease of contract farming with } \\
\text { agribusinesses is currently in progress. } \\
\text { However, some issues need to be } \\
\text { addressed, including corruption and non- } \\
\text { transparency during implementation of the } \\
\text { support programs (Ha et al., 2015b). } \\
\text { The extension network in this area can be } \\
\text { evaluated stronger than that in the NMR. } \\
\text { Yet, communication and coordination } \\
\text { between the extension network with other } \\
\text { local partners (farmers' associations and } \\
\text { local authorities) should be improved (Ha } \\
\text { et al., 2015b). }\end{array}$ & $\begin{array}{l}\text { Inappropriate land use management has } \\
\text { been reported as one of the major } \\
\text { hindrances to livelihood development of } \\
\text { the women smallholder farmers in the } \\
\text { region (Trinh, 2014). This has been } \\
\text { explained by the "top-down government } \\
\text { policies" that ignore the actual conditions } \\
\text { (biophysical and human factors) at the } \\
\text { localities. Therefore, poverty is still an } \\
\text { unsolved problem in this region (Yen et } \\
\text { al., 2013). } \\
\text { Extension services through training and } \\
\text { technology transfer programs are } \\
\text { available in the remote farming } \\
\text { communities (Yen, 2013). However, this } \\
\text { technology transfer efforts are } \\
\text { questionable in terms of the relevance and } \\
\text { quality of the education material. This } \\
\text { also lead to low adoption rates of } \\
\text { technology (Linh et al., 2015). }\end{array}$ \\
\hline
\end{tabular}

373 As discussed, having a number of similarities regarding their multidimensional challenges as

374 being smallholder farmers under the same political system, the women farmers in the two

375 regions have rather distinctive nuances due to both human factors and regional settings. 
376 These lead to the significant differences in terms of their prioritized needs and what they

377 regard as the main determinants of their quality of life.

378 The women in NMR have to face more challenging issues due to a number of reasons. Those

379 include unfavourable biophysical conditions, further away from markets, lack of information,

380 conventional subsistence production habits, language barriers, high level of gender-bias 381 conception against women as well as inappropriate supporting policies. Therefore, the

382 multiple issues could only be addressed by a more holistic approach and coordinated actions

383 rather than the traditional "piecemeal" approach. A complete process towards defining

384 systemic interventions and developing an overall integrated management plan as presented in

385 (Ha et al., 2015c) could be applied in the NMR as well to help address the multidimensional 386 problems that the women farmers are facing.

\section{IV. CONCLUSION}

388 This study provided in-depth insights to the current situations of women farmers in the two

389 regions. Though having some similarities, the regional differences in terms of geographical,

390 natural and human factors reveal a more vulnerable situation of the women farmers in the

391 NMR. This study has also highlighted potential levers for systemic interventions to address

392 their respective challenges.

393 The interrelationships amongst different factors in the two systems models suggest a need for

394 engaging relevant stakeholders in the problem structuring and decision making processes.

395 This will ensure the provision of more practical and rational policy recommendations for

396 coordinated actions to improve the lives of the women farmers in the two regions. 
397 It became clear that solving specific challenges of the women smallholder farmers in both 398 regions requires a holistic view to analyse the situation in more depth for adequate 399 interventions. This is because they are part of and influenced by bigger systems (rural 400 households and farming communities) and their complexity where various factors 401 (biophysical, social, economic, political and cultural) are intertwined. It is important that this must be taken into consideration for appropriate approaches and interventions in each specific locality.

404 This study provides both theoretical and practical contributions in agricultural systems 405 research and development. It introduces a new approach and systems tools in dealing with 406 complex problems of agricultural systems in the studied contexts. Given the generic nature of 407 the approach and process steps, the systems approach and tools can be applied to solve 408 complex problems in other contexts around the world. This study has proven that the traditional top-down and/or supply-driven approach is clearly inappropriate, which does not

410 address the real needs of local people and thus not lead to sustainable outcomes. The 411 traditional approach tends to solve immediate problems such as labour hardship, while it 412 ignores the fact that the lives of the women farmers are influenced by various factors beyond 413 their production systems. The study addresses the drawbacks of a so called "silo thinking" in 414 many development efforts in Vietnam as pointed out by a number of authors (e.g. Bosch et 415 al., 2013; Culas, 2012; Paris \& Chi, 2005). The systems approach also helps to visualise 416 areas of interventions within the systems that need to engage relevant stakeholders for 417 coordinated actions towards sustainable outcomes.

418 Further research is recommended that will focus on market actor linkages for improved 419 market access and development of systemic management plans for improving the quality of 420 life of the women smallholder farmers in NMR. 


\section{ACKNOWLEDGEMENT}

423 The authors would like to express their gratitude to the Grand Challenges Explorations team,

424 Bill \& Melinda Gates Foundation and the University of Adelaide Business School for 425 providing the necessary funds to make this research possible. We are grateful to the 426 Haiphong People's Committee, Department of Agriculture \& Rural Development, the 427 Extension Centre, Department of Planning \& Investment, Department of Statistics and the 428 district extension network in Vietnam for their continuous cooperation and logistical and 429 financial support. Last but not least, a special thank you to all the women participants of Kien 430 Thuy, Vinh Bao, An Lao, and Tien Lang districts for their time and many invaluable 431 contributions to this research.

\section{REFERENCES}

434 Barrett CB, Bachke ME, Bellemare MF, Michelson HC, Narayanan S, Walker TF. 2012. 435 Smallholder participation in contract farming: Comparative evidence from five countries. 436 World Development 40(4): 715-730.

437 Bawden RJ. 1991. Systems thinking and practice in agriculture. Journal of Dairy Science 438 74(7): 2362-2373.

439 Bosch OJH, Nguyen NC, Ha TM, Banson KE. 2015. Using a systemic approach to improve 440 the quality of life for women in small-scale agriculture: Empirical evidence from Southeast 441 Asia and Sub-Saharan Africa. Paper presented at the 3rd International Symposium on 442 Advances in Business Management Toward Systemic Approach, 21-23 January 2015, 443 Perugia, Italy. In Dominici et al. (2015) BoA-B.S.LAB-2015: 280-285.

444 Bosch OJH, Nguyen NC, Maeno T, Yasui T. 2013. Managing Complex Issues through 445 Evolutionary Learning Laboratories. Systems Research and Behavioral Science 30(2): 116446135.

447 Castella J-C, Boissau S, Trung TN, Quang DD. 2005. Agrarian transition and lowland448 upland interactions in mountain areas in northern Vietnam: application of a multi-agent 449 simulation model. Agricultural systems 86(3): 312-332. 
450 CEMA. 2010. List of 62 poorest districts of Vietnam. 451 http://cema.gov.vn/wps/portal/ubdt/vanban/chitiet/!ut/p/c4/04_SB8K8xLLM9MSSzPy8xBz9 452 CP0os3hnd0cPE3MfAwN D3dzA09P76CgAEtLQwtPM 2CbEdFADEXcbk!/?WCM_GLO 453 BAL_CONTEXT=/wps/wcm/connect/ubdt/cema/vanban/c6a16d804f4496ddb571b742680f1 454 aa4.

455 Chi PVQ, Fujimoto A. 2012. Land tenure and tenancy conditions in relation to rice 456 production in three villages in the Red River Delta, Vietnam. Journal of ISSAAS 457 (International Society for Southeast Asian Agricultural Sciences) 18(1): 31-48.

458 Clement F, Amezaga JM. 2013. Conceptualising context in institutional reforms of land and 459 natural resource management: the case of Vietnam. International Journal of the Commons 460 7(1): 140-163.

461 Culas C. 2011. States, Hmong, and Markets: Comparing "Ethnic Markets" in Luang 462 Phrabang (Laos) and Sapa - Bac Ha (Vietnam) Paper presented at the Hmong in Comparative 463 Contexts Conference: The Hmong Studies Consortium, Center for Southeast Asian Studies, 464 4-6 March, 2011.

465 Culas C. 2012. Understanding and using socioeconomic data on ethnic farmers to prepare for 466 implementation and scaling up of CA projects. Paper presented at the The 3rd International 467 Conference on Conservation Agriculture in Southeast Asia, December 10-15, 2012, Hanoi, 468 Vietnam.

469 DARDLC. 2012. Annual summary Report of Department of Agriculture and Rural 470 Development in Lao Cai: Department of Agriculture and Rural Development in Lao Cai, Lao 471 Cai Portal.

472 Dixon JA, Gibbon DP, Gulliver A. 2001. Farming systems and poverty: improving farmers' 473 livelihoods in a changing world. FAO: Rome.

474 Eastwood C, Chapman D, Paine M. 2012. Networks of practice for co-construction of 475 agricultural decision support systems: Case studies of precision dairy farms in Australia. 476 Agricultural Systems 108: 10-18.

477 FAO. 2002. FAO Rice Information. Food and Agriculture organization of the united nations 478 (FAO): Rome, Italy.

479 FAO. 2010. National gender profile of agricultural households: Vietnam. In FAO/SIDA 480 Partnership Cooperation within the Field of Rural Development. Food and Agriculture 481 Organization of the United Nations: Hanoi.

482 FAO. 2011. "Strengthening Capacities to Enhance Coordinated and Integrated Disaster Risk 483 Reduction Actions and Adaptation to Climate Change in Agriculture in the Northern 484 Mountain Regions of Viet Nam". In Training Needs Assessment for Provincial and District 485 Staff on Forecast Products and Early Warning Information FAO: Hanoi.

486 FAO. 2012. Baseline Survey of Phu Tho Province. http://www.fao.org/climatechange/34114487 08e8159536aded43df71e7419579898d8.pdf. 
488 Fischer E, Qaim M. 2012. Linking smallholders to markets: determinants and impacts of 489 farmer collective action in Kenya. World Development 40(6): 1255-1268.

490 Florin MJ, van Ittersum MK, van de Ven GW. 2013. Family farmers and biodiesel 491 production: Systems thinking and multi-level decisions in Northern Minas Gerais, Brazil. 492 Agricultural Systems 121: 81-95.

493 Gates-Foundation. 2013. Grand Challenges Explorations Round 11: Labor Saving Strategies 494 and Innovations for Women Smallholder 495 http://www.grandchallenges.org/Explorations/Topics/Pages/WomenSmallholderFarmersRou 496 nd11.aspx [02 August 2013].

497 Gregorich C. 2016. Seattle Sister Cities: Haiphong, Vietnam. 498 http://www.seattle.gov/oir/sister-cities/seattles-21-sister-cities/haiphong [15 August 2016].

499 GSO. 2013. Area, population and population density in 2013 by province by Cities, 500 provincies and Items. http://www.gso.gov.vn/default_en.aspx?tabid=774.

501 Ha TM. 2008. Impacts of bioslurry use on aquaculture in Bac Ninh province. Final research 502 report, the National Biogas Program, A joint program between MARD and SNV: Hanoi.

503 Ha TM, Bosch OJH, Nguyen NC. 2015a. Defining the real needs of women smallholders in 504 Vietnam: the importance of grassroots participation and multi-stakeholder collaboration. 505 International Journal of Business and Management Review 3(2): 35-58.

506 Ha TM, Bosch OJH, Nguyen NC. 2015b. Establishing and Evolutionary Learning Laboratory 507 for improving the quality of life of Vietnamese women in small-scale agriculture: Part I - The 508 current situation. Journal of Systems Research and Behavioral Science In Press (early view: 509 http://onlinelibrary.wiley.com/doi/10.1002/sres.2346/abstract).

510 Ha TM, Bosch OJH, Nguyen NC. 2015c. Establishing and Evolutionary Learning Laboratory 511 for improving the quality of life of Vietnamese women in small-scale agriculture: Part II 512 Systemic interventions. Systems Research and Behavioral Science 33(3): 341-359.

513 Ha TM, Bosch OJH, Nguyen NC. 2015d. Necessary and sufficient conditions for 514 agribusiness success of small-scale farming systems in Northern Vietnam. Business and 515 Management Studies 1(2): 36-44.

516 Hazell PB. 2005. Is there a future for small farms? Agricultural Economics 32(s1): 93-101.

517 Hazell PB, Rahman A (eds). 2014. New Directions for Smallholder Agriculture Oxford 518 University Press: Oxford.

519 IFAD. 2011. Rural Income Diversification Project in Tuyen Quang Province: Project 520 completion report validation, International Fund for Agricultural Development.

521 IFAD. 2013. Gender and rural development brief: Southeast Asia, International Fund for 522 Agricultural Development: Rome. 
523 Kabeer N. 2003. Gender mainstreaming in poverty eradication and the millennium 524 development goals: A handbook for policy makers and other stakeholders. Commonwealth 525 Secretariat: Lodon.

526 Kelly K. 2011. Vietname case study (preliminary findings): Women in education leadership and management. Paper presented at the IIEP Policy Forum on Gender Equality in Education, Paris.

529 Lamprinopoulou C, Renwick A, Klerkx L, Hermans F, Roep D. 2014. Application of an 530 integrated systemic framework for analysing agricultural innovation systems and informing 531 innovation policies: Comparing the Dutch and Scottish agrifood sectors. Agricultural Systems 532 129: 40-54.

533 Lapar MLA, Binh VT, Son NT, Tiongco M, Jabbar M, Staal S. 2006. The role of collective 534 action in overcoming barriers to market access by smallholder producers: some empirical 535 evidence from Northern Vietnam. Paper presented at the Workshop on" Collective Action

537 LCPPC. 2011. Transport Connection in Northern Mountainous Provinces Project Gender 538 Action and Ethnic Minority Development Plan Lao Cai Province. 539 http://www.adb.org/sites/default/files/linked-documents/41433-013-vie-gaemdpab-05.pdf $540 \quad$ [16th Sep 2015.

541 Le TTL. 2014. Assessment of the sustainability of the rice-maize cropping system in the Red 542 River Delta of Vietnam and developing reduced tillage practices in rice-maize system in the area. Journal of Vietnamese Environment 5(1): 1-7.

544 Linh TT, Nanseki T, Chomei Y. 2015. Identification of information sources influencing the 545 technical inefficiency of crop farmers in Vietnam. Asian Journal of Science and Technology 546 6(8): 1677-1683.

547 Maani KE. 2013. Decision-making for climate change adaptation: a systems thinking 548 approach, The National Climate Change Adaptation Research Facility: Gold Coast, QLD, 549 Australia; 67.

550 Maani KE, Canava RY. 2007. Systems thinking, system dynamics: Managing change and 551 complexity (2nd ed.). Prentice Hall, Auckland, NZ.

552 Macadam RD, Packham RG. 1989. A Case Study in the Use of Soft Systems Methodology: 553 Restructuring an Academic Organisation to Facilitate the Education of Systems 554 Agriculturalists. Agricultural Systems 30: 351-367.

555 Mainland DD. 1994. A decision support system for dairy farmers and advisors. Agricultural 556 Systems 45(2): 217-231.

557 Meadows D. 1999. Leverage points: Places to Intervene in a System. The Sustainability 558 Institute: Hartland, Vermont, USA. 
559 Minot N, Epprecht M, Anh TTT, Trung LQ. 2006. Income diversification and poverty in the

560 Northern Uplands of Vietnam. International Food Policy Research Institute: Washington DC.

561 Minot N, Hill RV. 2007. Developing and connecting markets for poor farmers. In 2020 Focus

562 Brief on the World's Poor and Hungry People. IFPRI: Washington.

563 Nghiem L. 2010. Activity and income diversification: trends, determinants and effects on 564 poverty reduction the case of the Mekong River Delta, Doctoral dissertation, Erasmus 565 University Rotterdam.

566 Nguyen CV. 2012. Ethnic Minorities in Northern Mountains of Vietnam: Poverty, Income 567 and Assets, University Library of Munich, Germany.

568 Norsys. 2013. Netica ${ }^{\mathrm{TM}}$ Application. http://www.norsys.com/netica.html.

569 Paracchini ML, Bulgheroni C, Borreani G, Tabacco E, Banterle A, Bertoni D, Rossi G, 570 Parolo G, Origgi R, De Paola C. 2015. A diagnostic system to assess sustainability at a farm 571 level: The SOSTARE model. Agricultural Systems 133: 35-53.

572 Paris TR, Chi TTN. 2005. The Impact of Row Seeder Technology on Women Labor: A Case 573 Study in the Mekong Delta, Vietnam. Gender, Technology and Development 9(2): 157-184.

574 Pham LV, Smith C. 2013. Agricultural sustainability in developing countries: an assessment 575 of the relationships between drivers and indicators in Hoa Binh province, Vietnam. 576 Agroecology and Sustainable Food Systems 37(10): 1144-1186.

577 Phi VT. 2012. Developing West-northern provinces of Vietnam" challenges to integrate with 578 GMS Market via China-Laos-Vietnam Triangle cooperation In Five triangle areas in the 579 Greater Mekong Subregion Ishida M (ed.), Bangkok Research Center, IDE-JETRO, 580 Bangkok, Thailand.

581 Safa MS. 2005. Socio-Economic factors affecting the income of small-scale agroforestry 582 farms in hill country areas in Yemen: A comparison of OLS and WLS determinants. Small583 scale Forest Economics, Management and Policy 4(1): 117-134.

584 Spedding C (ed). 1988. An introduction to agricultural systems Springer Science \& Business 585 Media: London.

586 Sterman JD. 2001. System dynamics modeling. California management review 43(4): 8-25.

587 Thinh HB. 2009. Rural employment and life: challenges to gender roles in Vietnam's 588 agriculture at present. Paper presented at the FAOIFAD-ILO workshop on Gaps, trends and 589 current research in gender dimensions of agricultural and rural employment: differentiated 590 pathways out of poverty, 31 March - 2 April 2009, Rome, Italy.

591 Trinh CT. 2014. Impacts of vegetable farming system on smallholders' livelihoods in North 592 Vietnam. A case of indigenous vegetables in Phu Tho and Lao Cai provinces. In Business 593 School. The University of Adelaide: Adelaide. 
594 Trinh CT, Ha TM, Bosch OJH, Nguyen NC. 2015. Using a Systems Approach to Improve the 595 Lives of Women Smallholder Farmers in the Northern Mountainous Region of Vietnam. 596 Paper presented at the 8th Vietnam Economists Annual Meeting (VEAM), 9-10 June 2015, 597 Thai Nguyen, Vietnam.

598 UN. 2013. UN-EU guidelines for financing of local cost in development in cooperation with 599 Vietnam: UN Agencies in Vietnam, the EU Delegation to Vietnam and the Ministry of 600 Planning and Investment of Vietnam.

601 Van Hung P, MacAulay TG, Marsh SP. 2007. The economics of land fragmentation in the 602 north of Vietnam*. Australian Journal of Agricultural and Resource Economics 51(2): 195603211.

604 Ventana ${ }^{\circledR}$. 2011. Vensim program (Release 6.1), Ventana Systems UK. 605 http://www.ventanasystems.co.uk/vensim-6-1-released-may-2013/ [10 August 2013].

606 Vester F. 2007. The Art of interconnected thinking: Tools and concepts for a new approach 607 to tackling complexity. MCB Publishing House: Munich, Germany.

608 Vien TD. 2003. Culture, environment, and farming systems in Vietnam's northern mountain 609 region. Southeast Asian Studies 41(2): 180-205.

610 Vien TD, Leisz SJ, Lam NT, Rambo AT. 2006. Using traditional swidden agriculture to 611 enhance rural livelhihoods in Vietnam's upland. Mountain Research and Development 26(3): $612 \quad 192-196$.

613 Villarreal M. 2000. Culture, agriculture and rural development: a view from FAO's 614 Population Programme Service. http:/www.fao.org/sd/wpdirect/wpre0132.htm [4 November 615 2013].

616 Yen BT. 2013. Integrated modelling for land use planning and policy recommendation in the 617 Northern Uplands of Vietnam. In Land Degradation and Development. Wageningen 618 University: Wageningen.

619 Yen BT, Visser SM, Hoanh CT, Stroosnijder L. 2013. Constraints on agricultural production 620 in the northern uplands of Vietnam. Mountain Research and Development 33(4): 404-415. 